\title{
A Case of Trichogerminoma
}

\author{
Minji Kim, M.D., Mira Choi, M.D., Jong Soo Hong, M.D., Jong Hee Lee, M.D. ${ }^{1}$, Soyun Cho, M.D. ${ }^{1}$ \\ Department of Dermatology, Seoul National University College of Medicine, ${ }^{1}$ Seoul National University Boramae Hospital, Seoul, Korea
}

Trichogerminoma is a rare neoplasm which was first described in 1992 and there is still controversy over its inclusion into the spectrum of trichoblastoma. A 79-year-old woman presented with a 5-year history of an asymptomatic nodule on the left posterior neck. Histologically, the lesion revealed a well-demarcated deep dermal nodule surrounded by a pseudocapsule. The tumor was composed of lobules with basophilic cells and some of the lobules displayed a distinctive pattern of densely packed 'cell balls' with peripheral condensation. Immunohistochemically, the tumor cells showed zonal CK5/6 immunoactivity in contrast with the negatively stained 'cell balls'. These characteristics were compatible with the diagnosis of trichogerminoma. We report here on a rare case of a hair germ tumor called trichogerminoma. (Ann Dermatol 22(4) 431 434, 2010)

\section{-Keywords-}

Cell ball, Hair germ tumor, Trichoblastoma, Trichogerminoma

\section{INTRODUCTION}

Tumors with hair follicular differentiation are difficult to differentiate due to the variety and similarity of the lesions. Trichogerminoma is an uncommon tumor that originates from hair germ cells and it was first reported on by Sau et al. ${ }^{1}$ in 1992 . Kazakov et al. ${ }^{2}$ showed the immunohistochemical uniqueness of trichogerminoma and the tumor was confirmed as being a unique entity, yet there is still controversy about this. Therefore, additional observation and research are needed to clarify its features.

Received September 16, 2009, Revised December 4, 2009, Accepted for publication December 7, 2009

Corresponding author: Soyun Cho, M.D., Department of Dermatology, Seoul National University Boramae Hospital, 39 Boramae-gil, Dongjak-gu, Seoul 156-707, Korea. Tel: 82-2-870-2386, Fax: 82-2870-3866, E-mail: sycho@snu.ac.kr
We report here on a case of trichogerminoma that developed on the nape of the neck of an elderly woman. We believe this is the first reported case of trichogerminoma in the Korean dermatological literature.

\section{CASE REPORT}

A 79-year-old woman presented with a 5-year history of an asymptomatic solitary nodule on the left posterior neck. It was a non-ulcerated, hemispheric, well-demarcated, movable nodule with no subjective symptoms (Fig. 1). The clinical diagnosis was epidermal cyst.

Excisional biopsy was performed and the lesion was totally removed. The gross examination of the surgical specimen demonstrated the mass to be $10 \times 10 \mathrm{~mm}$ in size with a maximum depth of $8 \mathrm{~mm}$. There was no internal necrosis or hemorrhage. Histological examination revealed a sharply demarcated, deep dermal and subcutaneous tumor surrounded by a pseudocapsule (Fig. 2A). The tumor had no connection to the overlying epidermis and the tumor consisted of variously sized nodules separated by a fibrocytic stroma. There was no cleft between the tumor nodules and stroma. The nodules were composed

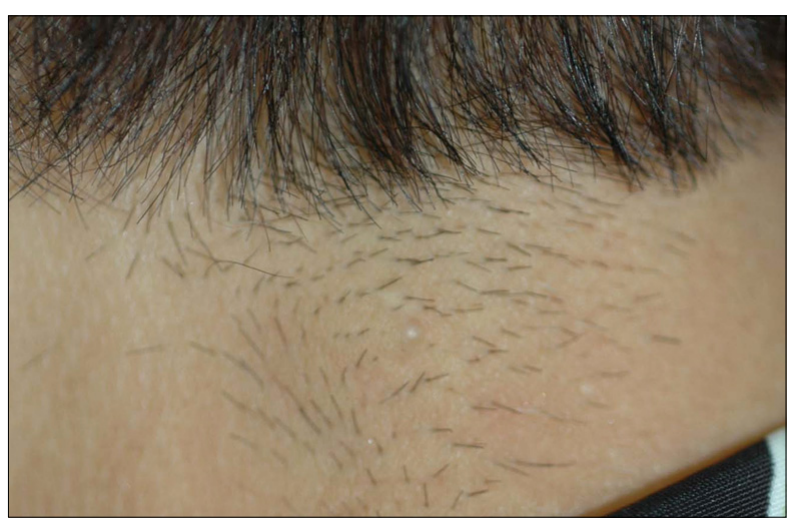

Fig. 1. A solitary non-ulcerated, hemispheric, well-demarcated, flesh-colored nodule on the posterior neck. 

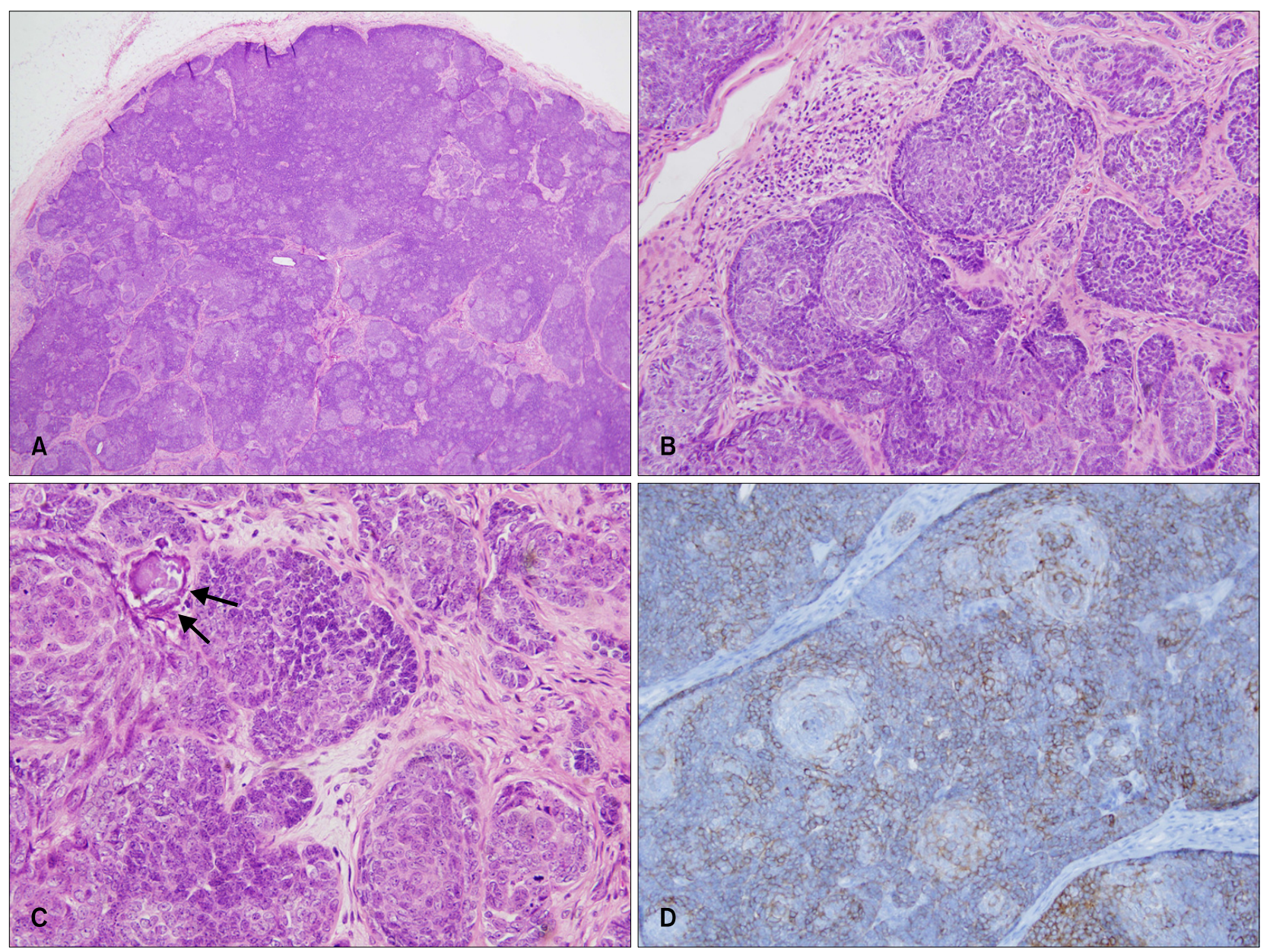

Fig. 2. (A) A well-demarcated tumor composed of basaloid lobules surrounded by a pseudocapsule in the deep dermis (H\&E, $\times 40)$. (B) Distinctive 'cell balls' of pale cells with peripheral condensation $(\mathrm{H} \& \mathrm{E}, \times 200)$. (C) Keratinous microcysts (arrow) are located in the eccentric part of the cell ball. The tumor cells extending from lobules make anastomosing strands or buds (H\&E, $\times 400)$. (D) The peripheral rim of the cell balls were prominently stained with anti-CK5/6, whereas the centrally located pale 'cell balls' expressed weaker staining with anti-CK5/6 (avidin-biotin complex, $\times 200$ ).

of smaller lobules that were made up of basophilic cells. Characteristically, within most of lobules, round nests or cell balls formed by dense, concentrically arranged basaloid cells were seen. Pale cells with prominent large nuclei and dispersed chromatin occupied the central area of the nests (Fig. 2B). Typical mitoses were frequently present in these areas. The outer layer of the lobules was composed of undifferentiated columnar basophilic cells that displayed peripheral palisading.

In some areas, cords of germ cells extended from the periphery of the lobules and formed buds into the stroma. In other areas, the basaloid cells showed keratinization with pyknotic nuclei and nuclear debris near the center of the lobule that resembled infundibular epithelium and these cells had developed keratinous microcysts (Fig. 2C). On the immunohistochemical examination, the tumor cells showed CK5/6 and p63 immunoreactivity, and they stained negatively for carcinoembryonic antigen (CEA). The peripheral rims of the cell balls were prominently stained with anti-CK5/6, whereas the center of the cell balls showed weaker staining with anti-CK5/6 (Fig. 2D). Most of the tumor cells were strongly stained with anti-p63 (data not shown). The dendritic cells scattered within the lobules and the stroma showed reactivity for S-100. The peripheral tumor cells and the hyaline-like thin membrane around some lobules were positive on periodic acid-Schiff staining.

There was no recurrence of tumor during 6-months follow up after complete excision.

\section{DISCUSSION}

Trichogerminoma is a rare tumor of hair germ epithelium, and it was first described by Sau et al. ${ }^{1}$ in 1992 . Most 
cases manifest as an asymptomatic solitary, slowly growing, deep-seated nodule, and the sizes vary from 7 to $40 \mathrm{~mm}$. It shows a male predominance and it generally occurs in middle-aged individuals. The involved sites are mostly on the face and less frequently on the scalp, trunk and extremities.

Histological examination reveals a well-demarcated dermal-subcutaneous nodule composed of smaller lobules with basaloid cells. The tumor cells are uniformly basophilic cells with round nuclei, dispersed chromatin and a tendency to show peripheral palisading. The distinctive feature of this tumor is "cell balls" that resemble hair bulbs, and these are concentrically arranged clear cells and peripheral condensation with little or no intervening stroma in some lobules. In the eccentric areas of the cell balls, the basaloid cells may present keratinization and they develop keratin microcysts that resemble abortive hair bulbs. In some areas, the tumor cells extending from lobules make anastomosing strands or buds. The various other histological features of this tumor include clear cell change that is suggestive of differentiation towards the outer root sheath of hair follicles and divergent sebaceous differentiation. The stroma is fibrocytic, and there is no retraction cleft between the lobules and stroma. Our case displayed several features of hair follicular differentiation, including the characteristic 'cell balls', cords of basaloid cells and keratin microcyst formation $^{1-4}$.

Immunohistochemically, the tumor cells express a ringlike staining pattern of cytokeratin markers such as AE1/ AE3, CK5/8 and CK5/6 with prominent immunoreactivity in the peripheral rims of the lobules ${ }^{2,3}$. These results may reflect outer root sheath differentiation ${ }^{5}$. As in other hair germ neoplasms, dendritic S-100 protein positive cells are scattered within the tumor. Sebaceous glandular differentiation can be defined by the epithelial membrane antigen and CEA staining ${ }^{3}$. CK20-positive Merkel cells are not found in the epidermis overlying the tumor. Periodic acid-Schiff stain reveals vitreous layer-like eosinophilic membranes surrounding many cell groups. Our case demonstrated the distinctive ring-like pattern of cytokeratin staining, which helped make the diagnosis of trichogerminoma. We studied the p63 immunoreactivity to clarify the differentiation potential of the tumor cells. However, there was no regional difference in the staining pattern between the two types of tumor cells, and p63 showed strong immunoreactivity in all tumor cells, the same as in other pilar tumors. In the hair follicle-derived tumors, the cell components originating from the outer root sheath cells or matrix cells expressed $p 63^{6}$.

There is still debate among dermatopathologists about trichogerminoma, and some consider it to be part of the spectrum of trichoblastoma. However, trichogerminoma differs from trichoblastoma in that it differentiates toward various pilosebaceous structures. In addition, trichoblastoma shows a different immunohistochemical pattern such as CK20-positive Merkel cells in the tumor and the overlying epidermis ${ }^{7}$, a half-moon pattern of calretininpositive tumor cells in almost every epithelial aggregation and the lack of zonal CK5/6 immunostaning ${ }^{8,9}$. Tumors of basaloid cells or hair follicular differentiation need to be differentiated from trichogerminoma. Trichoblastoma is made up of basaloid cells, but they display less advanced hair differentiation than trichogerminoma. The centrolobular areas of clear cells have been observed in trichoblastoma $^{8}$, but this pattern is not a dominant microscopic feature. Trichoepithelioma is a tumor that is made up of islands of basaloid cells with peripheral palisading and it has characteristic keratin cysts. Unlike trichogerminoma, it shows no nests of concentric pale cells. Trichilemmoma is characterized by periodic acidSchiff positive glycogen rich clear cells and palisaded

Table 1. Differential diagnosis of trichogerminoma

\begin{tabular}{|c|c|c|c|}
\hline Disease & Location & Tumor cells & Other architecture \\
\hline Trichogerminoma & Deep dermis-subcutis & $\begin{array}{l}\text { Various lobules composed of basaloid } \\
\text { cells, there is peripheral palisading, but } \\
\text { no retractional cleft }\end{array}$ & $\begin{array}{l}\text { Densely packed 'cell balls' with } \\
\text { peripheral condensation, } \\
\text { keratinous microcysts }( \pm)\end{array}$ \\
\hline Trichoepithelioma & Epidermis-superficial dermis & $\begin{array}{l}\text { Circumscribed basaloid tumor islands, } \\
\text { peripheral palisading, but no retraction } \\
\text { cleft }\end{array}$ & Horn cyst $(+)$ \\
\hline Trichilemmoma & Epidermis & $\begin{array}{l}\text { PAS-positive clear cells and peripheral } \\
\text { palisading of the basaloid cells }\end{array}$ & $\begin{array}{l}\text { Hyperkeratosis with the downward } \\
\text { lobular growth of the epidermis, } \\
\text { epidermal connection }(+)\end{array}$ \\
\hline Trichoblastoma & Deep dermis-subcutis & Circumscribed large basaloid neoplasm & No connection to the epidermis \\
\hline Basal cell carcinoma & Epidermis-superficial dermis & $\begin{array}{l}\text { Basaloid cells budding from the } \\
\text { epidermis or follicles, and peripheral } \\
\text { palisading with retraction cleft }(+)\end{array}$ & $\begin{array}{l}\text { Variable infiltrates of lymphocytes } \\
\text { and plasma cells }\end{array}$ \\
\hline
\end{tabular}


columnar cells at the periphery that rest upon a thickened basement membrane. Basal cell carcinoma with follicular differentiation is a tumor with basaloid cells budding from the epidermis or follicles with a horn cyst resembling a follicular structure. However, it shows a lack of papillar formation and there are no centrolobular balls of concentric pale cells. The different characteristics of each tumor from trichogerminoma are summarized in Table $1^{7,10}$.

Trichogerminoma has a benign course. All the cases, except for one case of undifferentiated carcinoma that developed from trichogerminoma and that ended in death due to metastasis and progression of the disease, have shown no recurrence after surgical removal ${ }^{1-4}$. Because of the potential of malignancy, complete excision of the tumor should be the treatment of choice.

\section{REFERENCES}

1. Sau P, Lupton GP, Graham JH. Trichogerminoma. Report of 14 cases. J Cutan Pathol 1992;19:357-365.

2. Kazakov DV, Kutzner $H$, Rutten A, Dummer R, Burg G, Kempf W. Trichogerminoma: a rare cutaneous adnexal tumor with differentiation toward the hair germ epithelium.
Dermatology 2002;205:405-408.

3. Tellechea O, Reis JP. Trichogerminoma. Am J Dermatopathol 2009;31:480-483.

4. Pozo L, Diaz-Cano SJ. Trichogerminoma: further evidence to support a specific follicular neoplasm. Histopathology 2005; 46:108-110.

5. Moll R, Divo M, Langbein L. The human keratins: biology and pathology. Histochem Cell Biol 2008;129:705-733.

6. Ivan D, Hafeez Diwan A, Prieto VG. Expression of p63 in primary cutaneous adnexal neoplasms and adenocarcinoma metastatic to the skin. Mod Pathol 2005;18:137-142.

7. Schulz T, Hartschuh W. Merkel cells are absent in basal cell carcinomas but frequently found in trichoblastomas. An immunohistochemical study. J Cutan Pathol 1997;24:14-24.

8. Ackerman $A B$, de Viragh $P A$, Chongchitnant N. Trichoblastoma. In: Ackerman AB, de Viragh PA, Chongchitnant $N$, editors. Neoplasms with follicular differentiation. Philadelphia: Lea \& Febiger, 1993:359-422.

9. Kurzen H, Esposito L, Langbein L, Hartschuh W. Cytokeratins as markers of follicular differentiation: an immunohistochemical study of trichoblastoma and basal cell carcinoma. Am J Dermatopathol 2001;23:501-509.

10. Rapini RP. Follicular neoplasm. In: Rapini RP, editor. Practical dermatopathology. Philadelphia: Elsevier Mosby, 2005:285-293. 